\title{
Factors Influencing Competitiveness of Unorganized Retail Outlets with Special Reference to Indian Retail Stores
}

\author{
Ajay Bahadur ${ }^{1}$ and Ram Krishna ${ }^{2}$ \\ ${ }^{1,2}$ Research Scholar, Department of Management, Faculty of Social Sciences, Dayalbagh \\ Educational Institute, Dayalbagh, Agra, U.P. - 282005, India
}

\begin{abstract}
Retailing in India is contributing the major part in Gross Domestic Product of the country as there are many organized retail outlets entering into India; still there are some factors due to which unorganized retail outlets are able to remain competitive in the market. The present study was conducted in Mathura, Agra, Hathras and Aligarh in Agra region of Uttar Pradesh, India. The retail industry in these areas has shown a tremendous growth in last few years for organized as well as unorganized retail stores. Unorganized sector has different strategies to compete with the organized sector to survive in the current environment. 21 attributes were selected for the study based on the previous studies which affect the competitiveness of unorganized retail stores. For analyzing the data collected, various tools have been used to generate some meaningful results out of it like Analysis of Variance, Exploratory Factor Analysis, Confirmatory Factor Analysis etc. Result shows that there are several factors preferred by the shoppers which affect the competitiveness of unorganized retail stores like smooth transaction and exchange, ambiance, merchandise mix etc. It can be concluded that these preferred factors have the significant impact on the competitiveness of unorganized retail outlets to better survive in the dynamic environment.
\end{abstract}

Keywords: Indian Retail Stores, Retail Stores Competitiveness, Small Business, Unorganized Retail Outlets, Unorganized Retailing.

\section{Introduction}

The retail business in India has emerged together of the foremost dynamic and quickest growing industries because of the entry of many national and international players. Indian retail business accounts for over ten per cent of the India's Gross Domestic Product (GDP) and considering the Indian retail business is that the fifth largest retail business the world. India's retail the is predicted to just about double to US\$ one trillion by 2020 from US\$ 600 billion in 2015, which is influenced by financial gain growth, attitudinal shifts and urbanization. Whereas the retail market is that the world expected to grow at 12 per cent every year, the trendy retail trade would expand double as quick at 20 per cent every year and ancient retail trade at 10 per cent. The Indian retail mercantilism has received Foreign Direct Investment (FDI) equity inflows of US\$ 935.74 million throughout Apr. 2000 to Dec. 2016, as per the report of Department of business Policies and Promotion (DIPP). As the increase in demand of commodity in several sectors as well as home appliances and client natural philosophy, several new players have invested with the Indian retail business as the retail industry in India has great potential. As per government initiatives, recently, Government of India (GOI) has allowed one hundred percent Foreign Direct Investment (FDI) in online retail of products and services through the automated route that helped in providing clarity on the prevailing business of massive e-commerce players' operating in India.

Big establishments in small cities like megastores, supermarkets and hypermarkets are affecting the buying patterns of shoppers to move towards organized retailing as organized retail stores understand the behavior of the shoppers and are acting accordingly. Shoppers in India are slowly moving towards the organized retailing. Unorganized retail stores need to understand the behavior of the shoppers and should formulate the strategies accordingly. It is clear that factors affecting shoppers behavior have an influence on the competitiveness of Indian retail industry. The factors affecting buying behavior of shoppers in organized and unorganized retailing are moreover same (Goel B., 2011).

\section{Theoretical Framework and Hypotheses Development}

Porter (1992) explained that competitive advantage over the other firms can be achieved only by taking 
the advantage of skills through which firm is able to gain tangible and sustainable business edge over others. Dholakia (2012) focused on the state of competitiveness along with how the competitive advantage is gained by industries in big countries by taking into consideration certain past cases. In their view of cases, competitive advantage is a mixture of performance and positional superiority with a result related to the competition that how a firm deploys their resources and skills. These resources and skills bring the positional competitive advantage like cost and differentiation by focusing on the productivity of the firm (Barney, 1991; Lado \& Wilson, 1994). Porter (1992) explained that there are three types of business strategies which are cost strategy, differentiation strategy and focus strategy. The most common strategy which is used by the firms to gain competitive advantage and to differentiate themselves from other firms is the generic strategy which can easily be changed based on the environmental conditions.

Some authors described that location of the firm is a variable which has high influence in achieving competitive advantage over other firms. This variable also helps the firm in achieving firm's success and in improving their financial performance (Bharadwaj et al., 1993; Fernie, 1995). Sherman (1997) revealed that price is the variable in the retail industry which influences the customer to purchase from that store and to gain the competitive advantage over other firms. The low price also forces the competitors to cut their prices as well. Swinyard (1997) explained the instore environment and the advanced technology used by the store have the influence on achieving competitive advantage over other firms like customer and staff touch screen appliances, consumer smart cards, self- scanning devices, intelligent trolleys etc. There are a number of big retail stores operating which are creating competition to unorganized retail stores based on these attributes (Shaw et al., 1992 \& Arnold et al., 1998). He described that the success of unorganized retailers depends on identifying, understanding and fulfilling the needs of the customer better than the organized retailers if they want to survive in the competitive environment. It is easy for the unorganized retailers because they are operating in a local market (Mishra \& Dash, 2008). Sinha and Banerjee (2004) analyzed 43 different variables which are affecting the store choice behavior of the shoppers in the competitive market. Based on variables considered they extracted 6 different factors namely Merchandise, Service, Proximity, Patronized, Ambiance and others.

Ramakrishnan (2010) identified the response of small retailers towards the competition in the market created by organized retailers in Indian economy. For this purpose, he created clusters of retailers based on the success strategies they follow. The result of the study shows that there are some strategies like providing the value to the customer more than the price of product/ service, maintaining the personal relationship with the customer, providing additional services etc. is adopted to survive in the dynamic environment. Goldman (1999) analyzed the importance of understanding the customer preference which results in success of any business organization. This study was conducted in various cities of Gujarat. The respondents of the study were the shoppers who regularly visit 'mom and pop' shops and malls. The respondents were asked to provide various suggestions for 'mom and pop' shops so that they can remain competitive in the business environment. The results show that here are some strategies which need to follow like careful management of inventory, improve the display of goods, improve the business processes and maintain customer relationship to have the better influence in the minds of the customer.

A study by Mishra (2008) with the objective of identifying the difference between Kirana stores and supermarkets. For this, 44 different variables were taken into consideration. Study extracted 11 factors out of 44 variables namely location, planned shopping, store brands and parking facilities, unplanned purchases, hedonic shopping, store cleanliness and product quality, in- store conveniences, travel convenience, specific day shopping, helpful and trustworthy salespeople and multiple stores. Oppewal \& Timmermans (1997) conducted the study in European countries considering 183 retailers with an objective to identify the importance of perceived image by the shoppers and the positioning strategies used by the retailers in the competitive business environment. The result of the study shows that service is the factor which an average retailer uses to differentiate themselves from others. The study identified the 6 dimensions which have an influence on perceived image of the shoppers which are interior, service, location, price, product quality and selection.

Fulmer et al., (1998) identified that the significance of sustaining and developing competitive advantage is required when the market conditions and competitions are changing frequently. Zameer A. (2011) explained that sustaining the competitive advantage for a longer period of time is very much useful for the industries. There are a number of studies available which identifies that sustaining competitive advantage provides better edge to the firm for better survive in the changing environment (Hawes \& Crittenden, 1984).

Based on the above literature it can be concluded that the unorganized retail industry is an unexplored industry for research. Very few studies have focused on preference of shoppers and store attributes in unorganized retailing and there are no studies available regarding the competitiveness of unorganized retailing as compared to organized 
retailing in Agra region of Uttar Pradesh in India. In this context, this study is a significant contribution to the research on factors affecting the competitiveness of unorganized retail outlets in Agra region of Uttar Pradesh in India.

\section{Objectives of the Study}

First objective is to identify the factors affecting competitiveness of unorganized retail outlets. Second objective is to analyze the perception of shoppers towards unorganized retail stores attributes and last is analyze the influence of factors affecting competitiveness of unorganized retail outlets.

\section{Hypotheses of the study}

Based on the review of literature, following hypotheses can be formed:

$\mathbf{H}_{\mathbf{a}}$ 1: Factors influencing competitiveness of unorganized retail outlets are dependent to each other.

2. $\mathbf{H}_{\mathbf{a}}$ 2: There is a significant difference between factors based on shoppers preference and demographic factors of shoppers:

(i) $\mathbf{H}_{\mathbf{a}} \mathbf{2 a}$ : There is a significant difference between factors affecting shoppers preference and different age category.

(ii) $\mathbf{H}_{\mathbf{a}} \mathbf{2 b}$ : There is a significant difference between factors affecting shoppers preference and different gender category.

(iii) $\mathbf{H}_{\mathbf{a}} \mathbf{2 c}$ : There is a significant difference between factors affecting shoppers preference and different income category.

(iv) $\mathbf{H}_{\mathbf{a}} \mathbf{2 d}$ : There is a significant difference between factors affecting shoppers preference and different qualification category.

(v) $\mathbf{H}_{\mathbf{a}}$ 2e: There is a significant difference between factors affecting shoppers preference and different occupation category.

\section{Research methodology}

The study is descriptive in nature. Data were collected from the shoppers who visited the retail stores in four selected cities of Agra region in India. Questions were asked regarding demographics of the shoppers such as age, gender, income, qualification and occupation. 21 attributes affecting the shoppers' preference was selected from previous studies and was presented to shoppers. These attributed was measured using the five-point rating scale. The pilot study was conducted by the researcher in September 2017 and after that actual data was collected from October 2017 to March 2018. The respondents were above 20 years of age. The study was conducted in four major cities like Mathura, Agra, Hathras and Aligarh. 400 questionnaire were distributed which consist 100 questionnaire in each city. 382 questionnaire were received back which were used for analyzing the data. The response rate was $98 \%, 95 \%, 92 \%$ and $97 \%$ respectively. The overall response rate was $95.5 \%$. The researcher made every possible effort for keeping the response rate as high as possible. For analyzing the data Analysis of Variance (ANOVA), Exploratory Factor Analysis (EFA), Confirmatory Factor Analysis (CFA) etc. was used.

\section{Results}

\subsection{Analysis of Shoppers Profile}

The data which was collected from the respondents on various attributes affecting competitiveness of unorganized retail outlets has analyzed using various statistical tools and techniques to better present the results interpreted out of it and to test the various hypotheses related to the study.

Table 1: Sample Size by Location

\begin{tabular}{|l|c|c|}
\hline & $\begin{array}{c}\text { Respondents } \\
\text { Approached }\end{array}$ & $\begin{array}{c}\text { Valid } \\
\text { Responses }\end{array}$ \\
\hline Mathura & 100 & 98 \\
\hline Agra & 100 & 95 \\
\hline Hathras & 100 & 92 \\
\hline Aligarh & 100 & 97 \\
\hline Total & 400 & 382 \\
\hline
\end{tabular}

Table 1 is showing the number of respondents from each city approached and the number of completed questionnaires received from them. 382 out of 400 questionnaires were received back from the respondents. The response rate was $98 \%, 95 \%, 92 \%$ and $97 \%$ respectively. The overall response rate was $95.5 \%$.

\section{Perception Level of Shoppers on Store Attributes}

Table 2: Demographic Profile of Shoppers

\begin{tabular}{|c|c|c|}
\hline $\begin{array}{c}\text { Demographic } \\
\text { Profile }\end{array}$ & $\begin{array}{c}\text { No. of } \\
\text { Respondents }\end{array}$ & $\begin{array}{c}\text { \% of } \\
\text { Respondents }\end{array}$ \\
\hline
\end{tabular}




\begin{tabular}{|c|c|c|}
\hline \multicolumn{3}{|l|}{ Age } \\
\hline 20-29 Years & 82 & $21.50 \%$ \\
\hline 30-39 Years & 132 & $34.50 \%$ \\
\hline 40-49 Years & 117 & $30.60 \%$ \\
\hline 50 and above & 51 & $13.40 \%$ \\
\hline Total & 382 & $100 \%$ \\
\hline \multicolumn{3}{|l|}{ Gender } \\
\hline Male & 223 & $58.40 \%$ \\
\hline Female & 159 & $41.60 \%$ \\
\hline Total & 382 & $100 \%$ \\
\hline \multicolumn{3}{|l|}{ Monthly Income } \\
\hline $\begin{array}{l}\text { Less than Rs. } \\
10,000\end{array}$ & 63 & $16.50 \%$ \\
\hline $\begin{array}{l}\text { Rs. } 10,001 \text { - Rs. } \\
30,000\end{array}$ & 94 & $24.60 \%$ \\
\hline $\begin{array}{l}\text { Rs. } 30,001 \text { - Rs. } \\
50,000\end{array}$ & 114 & $29.80 \%$ \\
\hline Above Rs. 50000 & 111 & $29.10 \%$ \\
\hline Total & 382 & $100 \%$ \\
\hline \multicolumn{3}{|l|}{ Qualification } \\
\hline Intermediate & 86 & $22.50 \%$ \\
\hline Graduate & 161 & $42.20 \%$ \\
\hline Post Graduate & 112 & $29.30 \%$ \\
\hline Other & 23 & $6 \%$ \\
\hline Total & 382 & 100 \\
\hline \multicolumn{3}{|l|}{ Occupation } \\
\hline Student & 57 & $14.90 \%$ \\
\hline Self Employed & 127 & $33.30 \%$ \\
\hline Service & 136 & $35.60 \%$ \\
\hline Housewives & 62 & $16.20 \%$ \\
\hline Total & 382 & $100 \%$ \\
\hline
\end{tabular}

Table 3: Shoppers Preference Level towards Various Attributes in Unorganized Stores

\begin{tabular}{|l|c|c|}
\hline Attributes (Unorganized) & Mean & $\begin{array}{c}\text { Std. } \\
\text { Deviation }\end{array}$ \\
\hline $\begin{array}{l}\text { Spacious \& clean } \\
\text { environment }\end{array}$ & 3.82 & 1.38 \\
\hline
\end{tabular}

\begin{tabular}{|l|c|c|}
$\begin{array}{l}\text { Products stocked with } \\
\text { freshness }\end{array}$ & 3.79 & 1.52 \\
\hline $\begin{array}{l}\text { Availability of global } \\
\text { products }\end{array}$ & 3.12 & 1.17 \\
\hline $\begin{array}{l}\text { Availability of products in } \\
\text { desired pack sizes }\end{array}$ & 3.84 & 0.67 \\
\hline $\begin{array}{l}\text { Availability of variety of } \\
\text { brands and products }\end{array}$ & 3.44 & 1.64 \\
\hline $\begin{array}{l}\text { Discounts \& promotion } \\
\text { schemes }\end{array}$ & 3.51 & 1.41 \\
\hline Fast \& efficient billing & 3.62 & 1.65 \\
\hline Prompt \& efficient staff & 4.11 & 1.43 \\
\hline Free home delivery & 3.68 & 0.85 \\
\hline Credit availability & 3.08 & 1.47 \\
\hline $\begin{array}{l}\text { Error- free sales } \\
\text { transactions and records }\end{array}$ & 3.79 & 1.67 \\
\hline $\begin{array}{l}\text { Loyalty programme } \\
\text { membership }\end{array}$ & 3.85 & 1.83 \\
\hline $\begin{array}{l}\text { Quick handling of } \\
\text { complaints }\end{array}$ & 4.23 & 0.52 \\
\hline Exchange policy & 3.89 & 1.63 \\
\hline $\begin{array}{l}\text { All modes of payment } \\
\text { accepted }\end{array}$ & 4.28 & 0.91 \\
\hline Relationship with the store & 3.76 & 1.54 \\
\hline Brand image & 3.54 & 1.86 \\
\hline Nearness to residence & 4.37 & 0.78 \\
\hline Convenient store timings & 3.92 & 1.71 \\
\hline Order is taken over phone & 3.42 & 1.58 \\
\hline Parking facilities & 3.28 & 1.63 \\
\hline
\end{tabular}

Table 2 is showing the demographic profile of the shoppers approached in four different cities of Agra region. Majority of the respondents were belong to 30 - 39 years $(34.5 \%)$ followed by $40-49(30.6 \%), 20-$ $29(21.5 \%)$ and above 50 years $(13.4 \%)$, male $(58.4 \%)$ followed by female $(41.6 \%)$, income group of 30001- 50000 (29.8\%) followed by above 50000 $(29.1 \%), 10001-30000(24.6 \%)$ and below 10000 $(16.5 \%)$, graduate in qualification $(42.2 \%)$ followed by post graduate $(29.3 \%)$, intermediate $(22.5 \%)$ and others $(6 \%)$, service category $(35.6 \%)$ followed by self- employed $(33.3 \%)$, housewives $(16.2 \%)$ and student $(14.9 \%)$.

Table 3 is showing the shoppers preference based on 21 attributes selected from previous studies that affect the competitiveness of unorganized retail outlets in four different cities of Agra region. The mean value of highly preferred attributes by the shoppers was Nearness to residence (4.37), all modes of payment accepted (4.28), Quick handling of complaints (4.23) and Prompt \& efficient staff (4.11). These preferred 
factors are the most influential attributes in unorganized retail outlets.

In Table 4 city wise preference of attributes by the shoppers has shown where it is noted that in Mathura most influential attributes are Prompt \& efficient staff (4.26), Quick handling of complaints (4.34), All modes of payment accepted (4.11) and Nearness to residence (4.18). Prompt \& efficient staff (4.14), Loyalty programme membership (4.08), Quick handling of complaints (4.06), All modes of payment accepted (4.43), Nearness to residence (4.02) and Convenient store timings (4.03) in Agra city. Availability of products in desired pack sizes (4.13), Quick handling of complaints (4.18), Exchange policy (4.12), all modes of payment accepted (4.35) and Nearness to residence (4.69) in Hathras city. Prompt \& efficient staff (4.06), Quick handling of complaints (4.33), all modes of payment accepted
(4.23) and Nearness to residence (4.60) in Aligarh City. In these cities, the attributes mentioned have higher influence towards unorganized retail stores as compare to other attributes. Nearness to residence, all modes of payment accepted and quick handling of complaints are the most influential attributes in all four cities. There are certain attributes whose influence is affected by a particular city. There is a significant difference between various attributes based on the city like Products stocked with freshness, Availability of variety of brands and products, Discounts \& promotion schemes, Free home delivery, Quick handling of complaints, All modes of payment accepted, Nearness to residence and Order is taken over phone whose $\mathrm{F}$ - value is greater than the critical value of 1.96. Results show that location does not affect most of the attributes but there are some attributes which differ on location.

Table 4: ANOVA Results for Store Attributes Preferences at Four Cities in Agra Region

\begin{tabular}{|c|c|c|c|c|c|}
\hline Attributes & Mathura & Agra & Hathras & Aligarh & F- Value \\
\hline $\begin{array}{c}\text { Spacious \& clean } \\
\text { environment }\end{array}$ & 3.64 & 3.93 & 3.76 & 3.95 & 1.57 \\
\hline $\begin{array}{l}\text { Products stocked with } \\
\text { freshness }\end{array}$ & 3.83 & 3.96 & 3.68 & 3.69 & $6.92 *$ \\
\hline $\begin{array}{l}\text { Availability of global } \\
\text { products }\end{array}$ & 3.21 & 3.08 & 3.04 & 3.14 & 1.64 \\
\hline $\begin{array}{c}\text { Availability of products in } \\
\text { desired pack sizes }\end{array}$ & 3.65 & 3.73 & 4.13 & 3.86 & 1.16 \\
\hline $\begin{array}{l}\text { Availability of variety of } \\
\text { brands and products }\end{array}$ & 3.4 & 3.63 & 3.27 & 3.46 & $4.61 *$ \\
\hline $\begin{array}{c}\text { Discounts \& promotion } \\
\text { schemes }\end{array}$ & 3.64 & 3.37 & 3.54 & 3.49 & $3.96^{*}$ \\
\hline Fast \& efficient billing & 3.43 & 3.83 & 3.53 & 3.69 & 1.02 \\
\hline Prompt \& efficient staff & 4.26 & 4.14 & 3.97 & 4.06 & 0.88 \\
\hline Free home delivery & 3.89 & 3.96 & 3.64 & 3.23 & $2.47 *$ \\
\hline Credit availability & 2.92 & 3.08 & 3.17 & 3.16 & 0.92 \\
\hline $\begin{array}{c}\text { Error-free sales transactions } \\
\text { and records }\end{array}$ & 3.88 & 3.71 & 3.62 & 3.93 & 1.18 \\
\hline $\begin{array}{c}\text { Loyalty programme } \\
\text { membership }\end{array}$ & 3.8 & 4.08 & 3.74 & 3.78 & 0.56 \\
\hline $\begin{array}{l}\text { Quick handling of } \\
\text { complaints }\end{array}$ & 4.34 & 4.06 & 4.18 & 4.33 & $4.06^{*}$ \\
\hline Exchange policy & 3.94 & 3.69 & 4.12 & 3.81 & 1.91 \\
\hline $\begin{array}{c}\text { All modes of payment } \\
\text { accepted }\end{array}$ & 4.11 & 4.43 & 4.35 & 4.23 & $5.37 *$ \\
\hline Relationship with the store & 3.8 & 3.87 & 3.96 & 3.42 & 1.48 \\
\hline Brand image & 3.58 & 3.38 & 3.74 & 3.47 & 0.35 \\
\hline Nearness to residence & 4.18 & 4.02 & 4.69 & 4.6 & $5.49 *$ \\
\hline Convenient store timings & 3.87 & 4.03 & 3.79 & 3.98 & 1.63 \\
\hline Order is taken over phone & 3.23 & 3.45 & 3.72 & 3.29 & $3.17 *$ \\
\hline Parking facilities & 3.59 & 3.24 & 3.27 & 3.01 & 0.97 \\
\hline
\end{tabular}

Factor Analysis

Exploratory Factor Analysis (EFA)
In Table 5, the Exploratory Factor Analysis (EFA) of the 21 attributes has been performed. The main objective of conducting exploratory factor analysis is to create a group for highly related attributes and data reduction. Convenience \& comfort explained the 
highest degree of variance $(24.379 \%)$, Merchandise mix explained second highest (17.744\%), Smooth transaction \& exchange (12.089\%), Store relationship (10.921\%), Ambiance $(9.630 \%)$, Value added facilities (7.329) and Attractive promotions (6.861\%). These extracted factors are able to explain the total variance of approximately $80 \%$. For extracting these factors Principle Component Analysis (PCA) has been used while considering criteria of Eigen value
$>1$. The table is also showing the value of Cronbach's Alpha. The value of Cronbach's Alpha is used to measure the reliability of the factors extracted. A value of more than 0.6 Cronbach's alpha is considered a good measure of scale of reliability (Nunnally, 1978). The value of Cronbach's Alpha for all seven factors are $.822, .797, .733, .818, .764, .810$ and .759 respectively which is greater than 0.6 .

Table 5: Factors Based on Store Attributes Preferences

\begin{tabular}{|c|c|c|c|c|}
\hline Factors & Loadings & $\begin{array}{l}\text { Eigen } \\
\text { Value }\end{array}$ & $\begin{array}{c}\% \text { of } \\
\text { Variance } \\
\text { Explained }\end{array}$ & $\begin{array}{c}\text { Cronbach's } \\
\text { Alpha }\end{array}$ \\
\hline \multicolumn{2}{|l|}{ Factor 1: Convenience \& Comfort } & 4.643 & 24.379 & 0.822 \\
\hline Quick handling of complaints & 0.826 & & & \\
\hline Nearness to residence & 0.798 & & & \\
\hline Convenient store timings & 0.782 & & & \\
\hline Loyalty programme membership & 0.814 & & & \\
\hline Order is taken over phone & 0.791 & & & \\
\hline \multicolumn{2}{|l|}{ Factor 2: Merchandise Mix } & 3.914 & $\mathbf{1 7 . 7 4 4}$ & $\mathbf{0 . 7 9 7}$ \\
\hline Products stocked with freshness & 0.823 & & & \\
\hline Availability of products in desired pack sizes & 0.623 & & & \\
\hline Availability of variety of brands and products & 0.54 & & & \\
\hline Brand image & 0.768 & & & \\
\hline \multicolumn{2}{|l|}{ Factor 3: Smooth Transaction \& Exchange } & 3.286 & 12.089 & 0.733 \\
\hline Fast \& efficient billing & 0.736 & & & \\
\hline Error-free sales transactions and records & 0.698 & & & \\
\hline Exchange policy & 0.584 & & & \\
\hline Parking facilities & 0.803 & & & \\
\hline \multicolumn{2}{|l|}{ Factor 4: Store Relationship } & 2.834 & 10.921 & 0.818 \\
\hline Prompt \& efficient staff & 0.885 & & & \\
\hline Relationship with the store & 0.827 & & & \\
\hline \multicolumn{2}{|l|}{ Factor 5: Ambiance } & 2.287 & 9.63 & 0.764 \\
\hline Spacious \& clean environment & 0.687 & & & \\
\hline All modes of payment accepted & 0.752 & & & \\
\hline \multicolumn{2}{|l|}{ Factor 6: Value Added Facilities } & 1.687 & 7.329 & $\mathbf{0 . 8 1}$ \\
\hline Free home delivery & 0.776 & & & \\
\hline Credit availability & 0.593 & & & \\
\hline \multicolumn{2}{|l|}{\begin{tabular}{|l|} 
Factor 7: Attractive Promotions \\
\end{tabular}} & 1.192 & 6.861 & 0.759 \\
\hline Availability of global products & 0.739 & & & \\
\hline Discounts \& promotion schemes & 0.688 & & & \\
\hline
\end{tabular}

\section{Confirmatory Factor Analysis (CFA)}

Table 6 is showing the results of Confirmatory Factor Analysis (CFA). CFA is used to check whether the factors extracted are valid and are able to fulfill the objectives of the study. Model Fit Indices are also calculated to measure whether the model used in the study is fit in all aspects. Average variance extracted (AVE) should be greater than 0.5 (Hair J. Black, 2010). By looking at the table it is clear that all values of AVE are greater than 0.5. The value of relative chisquare should be less than 2 (Kline, 1998 \& Ullman, 2003). In above table, all factors have chi- square value of less than 2 which are 1.658, 0.967, 1.274, $1.743,0.263,1.207$ and 0.839 respectively. The Value of Comparative Fit Index (CFI), Goodness of Fit
Index (GFI) and Normed Fit Index (NFI) should be greater than .90 (Byrne, 1994). In above table, all values of CFI, GFI and NFI are greater than 0.90 so it is clear that model is following these criteria as well. The value of Root Mean Square Error of Approximation (RMSEA) should be less than 0.08 (Byrne, 1994). Above table is showing that all factors are having the values as required, all values are less than 0.08 . The factors which were extracted are able to fulfill all the criteria mentioned in the table. As all factors are following all the conditions so it can be concluded that the model is fit for further testing and it can be used for further analysis in the study.

Table 6: Confirmatory Factor Analysis (CFA) Results Summary and Test for Model Fit 


\begin{tabular}{|l|c|c|c|c|c|c|c|}
\hline \multicolumn{1}{|c|}{ Factor Name } & $\begin{array}{c}\text { Cronbach's } \\
\text { Alpha }\end{array}$ & $\begin{array}{c}\text { Average } \\
\text { Variance } \\
\text { Extracted } \\
\text { (AVE) }\end{array}$ & $\begin{array}{c}\text { CMIN/ } \\
\text { d.f. }\end{array}$ & $\begin{array}{c}\text { Comparative } \\
\text { Fit Index } \\
\text { (CFI) }\end{array}$ & $\begin{array}{c}\text { Goodness of } \\
\text { Fit Index } \\
\text { (GFI) }\end{array}$ & $\begin{array}{c}\text { Normed Fit } \\
\text { Index } \\
\text { (NFI) }\end{array}$ & $\begin{array}{c}\text { Root Mean } \\
\text { Square Error } \\
\text { of } \\
\text { Approximation } \\
\text { (RMSEA) }\end{array}$ \\
\hline Convenience \& Comfort & 0.822 & 0.652 & 1.658 & 0.987 & 0.964 & 0.969 & 0.022 \\
\hline Merchandise Mix & 0.797 & 0.533 & 0.967 & 0.954 & 0.972 & 0.984 & 0.063 \\
\hline $\begin{array}{l}\text { Smooth Transaction \& } \\
\text { Exchange }\end{array}$ & 0.733 & 0.594 & 1.274 & 0.974 & 0.936 & 0.957 & 0.017 \\
\hline Store Relationship & 0.818 & 0.613 & 1.743 & 0.967 & 0.982 & 0.948 & 0.046 \\
\hline Ambiance & 0.764 & 0.671 & 0.263 & 0.949 & 0.981 & 0.963 & 0.027 \\
\hline Value Added Facilities & 0.810 & 0.528 & 1.207 & 0.947 & 0.936 & 0.939 & 0.030 \\
\hline Attractive Promotions & 0.759 & 0.591 & 0.839 & 0.928 & 0.926 & 0.919 & 0.071 \\
\hline
\end{tabular}

\section{Analysis of Factors based on Shoppers Demographics}

Table 7 shows that age group of 20- 29 is more cautious to convenience \& comfort as compared to other age categories. Merchandise mix is most preferred by age group of 50 and above followed by 20-29, 40-49 and 30-39. 30-39 years age group is less worried about merchandise mix. Convenience \& comfort and ambiance are the factor preferred by 20 29 years of age group. Table showing that there is a significant difference in Merchandise mix, smooth transaction \& exchange and ambiance based on different age categories. Convenience \& comfort and store relationship are preferred by 30-39 years of age as compared to other factors. Store relationship and ambiance are the two factors which are preferred by age group of $50 \&$ above compared with other factors.

Table 7: ANOVA Results for Shoppers Age Groups and Factors Preference

\begin{tabular}{|l|c|c|c|c|c|}
\hline \multirow{2}{*}{ Factors/ Age } & $\begin{array}{c}\mathbf{2 0 -} \\
\mathbf{2 9}\end{array}$ & $\begin{array}{c}\mathbf{3 0 -} \\
\mathbf{3 9}\end{array}$ & $\begin{array}{c}\mathbf{4 0 -} \\
\mathbf{4 9}\end{array}$ & $\begin{array}{c}\mathbf{5 0} \text { \& } \\
\text { Above }\end{array}$ & $\begin{array}{c}\text { F- } \\
\text { Value }\end{array}$ \\
\cline { 2 - 5 } & \multicolumn{5}{|c|}{ Mean } \\
\hline $\begin{array}{l}\text { Convenience } \\
\text { \& Comfort }\end{array}$ & 4.14 & 4.01 & 3.92 & 3.63 & 1.37 \\
\hline $\begin{array}{l}\text { Merchandise } \\
\text { Mix }\end{array}$ & 3.74 & 3.56 & 3.63 & 3.79 & $4.58^{*}$ \\
\hline $\begin{array}{l}\text { Smooth } \\
\text { Transaction } \\
\text { \& Exchange }\end{array}$ & 3.83 & 3.72 & 3.47 & 3.58 & $2.46^{*}$ \\
\hline $\begin{array}{l}\text { Store } \\
\text { Relationship }\end{array}$ & 3.75 & 4.05 & 3.89 & 4.08 & 0.59 \\
\hline Ambiance & 4.26 & 3.96 & 3.89 & 4.31 & $3.91 *$ \\
\hline $\begin{array}{l}\text { Value Added } \\
\text { Facilities }\end{array}$ & 3.64 & 3.27 & 3.24 & 3.56 & 1.52 \\
\hline $\begin{array}{l}\text { Attractive } \\
\text { Promotions }\end{array}$ & 3.57 & 3.25 & 3.18 & 3.42 & 1.73 \\
\hline Note: *significant at 5\% level \\
\hline
\end{tabular}

Table 8 is showing that Male preferred store relationship (4.00), ambiance (3.81), convenience \& comfort (3.76) and smooth transaction and exchange

(3.73) over other factors. Female prefer Ambiance (4.39) followed by convenience \& comfort, store relationship and merchandise mix whose mean values are $4.24,3.86$ and 3.83 respectively. The table is also showing that the difference in male and female preference for convenience \& comfort, Ambiance and attractive promotions is statistically significant.

Table 8: ANOVA Results for Shoppers Gender Groups and Factors Preference

\begin{tabular}{|l|c|c|c|}
\hline \multirow{2}{*}{ Factors/ Gender } & Male & Female & $\begin{array}{c}\text { t- } \\
\text { Value }\end{array}$ \\
\cline { 2 - 3 } & \multicolumn{2}{|c|}{ Mean } & $5.81^{*}$ \\
\hline $\begin{array}{l}\text { Convenience \& } \\
\text { Comfort }\end{array}$ & 3.76 & 4.24 & 1.64 \\
\hline Merchandise Mix & 3.52 & 3.83 & 1.71 \\
\hline $\begin{array}{l}\text { Smooth Transaction \& } \\
\text { Exchange }\end{array}$ & 3.73 & 3.54 & 0.82 \\
\hline Store Relationship & 4.00 & 3.86 & $4.36^{*}$ \\
\hline Ambiance & 3.81 & 4.39 & 1.67 \\
\hline $\begin{array}{l}\text { Value Added } \\
\text { Facilities }\end{array}$ & 3.42 & 3.32 & $2.69^{*}$ \\
\hline Attractive Promotions & 3.26 & 3.40 & \\
\hline Note: *significant at 5\% level & & \\
\hline
\end{tabular}

In Table 9 Income group of less than 10000 prefer store relationship (4.15) as compared to other factors. Income group of 10001- 30000 prefer ambiance (4.29) and smooth transaction \& exchange (4.05). Convenience \& comfort (4.18) is preferred by more than 50000 income group followed by 30001- 50000, less than 10000 and 10001- 30000 whose mean value is $3.97,3.82$ and 3.78 respectively. The factor which differs significantly based on the income category is convenience \& comfort, smooth transaction \& exchange, store relationship and attractive promotions.

Table 9: ANOVA Results for Shoppers Income Groups and Factors Preference

\begin{tabular}{|c|c|c|c|c|c|}
\hline \multirow{2}{*}{$\begin{array}{c}\text { Factors/ } \\
\text { Income }\end{array}$} & $<\mathbf{1 0 , 0 0 0}$ & $\begin{array}{c}\mathbf{1 0 , 0 0 1} \\
-\end{array}$ & $\begin{array}{c}\mathbf{3 0 , 0 0 1} \\
\mathbf{3 0 , 0 0 0}\end{array}$ & $\begin{array}{c}\mathbf{5 0 , 0 0 0} \\
\mathbf{5 0 0 0 0}\end{array}$ & \multirow{5}{*}{$\begin{array}{c}\text { F- } \\
\text { Value }\end{array}$} \\
\cline { 2 - 5 } & \multicolumn{5}{|c|}{ Mean } \\
\hline $\begin{array}{l}\text { Convenience } \\
\text { \& Comfort }\end{array}$ & 3.82 & 3.78 & 3.97 & 4.18 & $3.67^{*}$ \\
\hline
\end{tabular}




\begin{tabular}{|l|c|c|c|c|c|}
$\begin{array}{l}\text { Merchandise } \\
\text { Mix }\end{array}$ & 3.52 & 3.74 & 3.80 & 3.49 & 1.83 \\
\hline $\begin{array}{l}\text { Smooth } \\
\text { Transaction } \\
\text { \& Exchange }\end{array}$ & 3.61 & 4.05 & 3.46 & 3.53 & $5.16^{*}$ \\
\hline $\begin{array}{l}\text { Store } \\
\text { Relationship }\end{array}$ & 4.15 & 3.92 & 3.81 & 3.97 & $4.11^{*}$ \\
\hline Ambiance & 3.72 & 4.29 & 3.96 & 4.13 & 1.49 \\
\hline $\begin{array}{l}\text { Value Added } \\
\text { Facilities }\end{array}$ & 3.28 & 3.47 & 3.12 & 3.63 & 0.32 \\
\hline $\begin{array}{l}\text { Attractive } \\
\text { Promotions }\end{array}$ & 3.42 & 3.53 & 3.18 & 3.23 & $3.94 *$ \\
\hline Note: *significant at 5\% level \\
\hline
\end{tabular}

Table 10: ANOVA Results for Shoppers Qualification Groups and Factors Preference

\begin{tabular}{|c|c|c|c|c|c|}
\hline \multirow[t]{2}{*}{$\begin{array}{c}\text { Factors/ } \\
\text { Qualification }\end{array}$} & 离: & 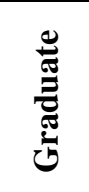 & 它蒡 & $\stackrel{\grave{\Xi}}{\bar{\Xi}}$ & \multirow[t]{2}{*}{ 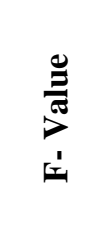 } \\
\hline & \multicolumn{4}{|c|}{ Mean } & \\
\hline $\begin{array}{l}\text { Convenience } \\
\& \text { Comfort }\end{array}$ & 4.13 & 3.86 & 3.92 & 4.03 & 1.45 \\
\hline $\begin{array}{l}\text { Merchandise } \\
\text { Mix }\end{array}$ & 3.74 & 3.33 & 3.95 & 3.98 & 1.73 \\
\hline $\begin{array}{l}\text { Smooth } \\
\text { Transaction \& } \\
\text { Exchange }\end{array}$ & 3.82 & 3.91 & 3.07 & 3.87 & 0.84 \\
\hline $\begin{array}{l}\text { Store } \\
\text { Relationship }\end{array}$ & 3.89 & 4.07 & 3.93 & 3.52 & $3.07 *$ \\
\hline Ambiance & 4.04 & 4.09 & 3.97 & 4.01 & 0.42 \\
\hline $\begin{array}{l}\text { Value Added } \\
\text { Facilities }\end{array}$ & 3.48 & 3.39 & 3.26 & 3.37 & $4.58^{*}$ \\
\hline $\begin{array}{l}\text { Attractive } \\
\text { Promotions }\end{array}$ & 3.62 & 3.18 & 3.24 & 3.41 & $6.13^{*}$ \\
\hline
\end{tabular}

Table 10 shows that there are certain factors which are different based on the qualification of the shoppers. Shoppers in various categories prefer different factors; Shoppers in post graduate category prefer ambiance (3.97), merchandise mix (3.95) and store relationship (3.93) while in graduate category ambiance (4.09) and store relationship (4.07) are most preferred. Based on qualification store relationship (3.07), value added facilities (4.58) and attractive promotions (6.13) differ significantly.

Table 11 is showing that ambiance (4.16) is the most preferred factor for student while store relationship (4.17) is most preferred factor for service category shoppers as compared to other factors. Smooth transaction and exchange are preferred by service category (3.74) followed by self- employed, student and housewives whose mean value is $3.67,3.58$ and 3.48 respectively. Value added facilities are most preferred by self- employed category (3.47) while least preferred by student category (3.14). The factors which differ significantly based on occupation of the shoppers are smooth transaction \& exchange, ambiance and value added facilities.

Table 11: ANOVA Results for Shoppers Occupational Groups and Factors Preference

\begin{tabular}{|c|c|c|c|c|c|}
\hline \multirow[t]{2}{*}{$\begin{array}{c}\text { Factors/ } \\
\text { Occupation }\end{array}$} & 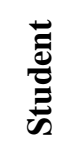 & 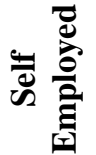 & 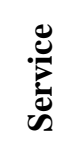 & 离 & \multirow[t]{2}{*}{ 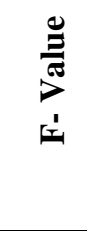 } \\
\hline & \multicolumn{4}{|c|}{ Mean } & \\
\hline $\begin{array}{l}\text { Convenience } \\
\& \text { Comfort }\end{array}$ & 3.84 & 4.00 & 3.98 & 3.95 & 0.74 \\
\hline $\begin{array}{l}\text { Merchandise } \\
\text { Mix }\end{array}$ & 3.42 & 3.59 & 3.63 & 3.86 & 1.86 \\
\hline $\begin{array}{l}\text { Smooth } \\
\text { Transaction } \\
\text { \& Exchange }\end{array}$ & 3.58 & 3.67 & 3.74 & 3.48 & $3.52 *$ \\
\hline $\begin{array}{l}\text { Store } \\
\text { Relationship }\end{array}$ & 3.61 & 3.68 & 4.17 & 3.82 & 1.72 \\
\hline Ambiance & 4.16 & 4.15 & 3.94 & 3.98 & $7.38 *$ \\
\hline $\begin{array}{l}\text { Value Added } \\
\text { Facilities }\end{array}$ & 3.14 & 3.47 & 3.42 & 3.29 & $6.23^{*}$ \\
\hline $\begin{array}{l}\text { Attractive } \\
\text { Promotions }\end{array}$ & 3.38 & 3.43 & 3.18 & 3.35 & 1.27 \\
\hline
\end{tabular}

\section{Managerial Implications}

Retail is an industry which caters to the last stage of distribution, and thus, as per its definition, it breaks bulk for the consumer to suit the specific need of every shopper. Shoppers decision making has always been an important aspect of analysis for a marketer. The factors that act to pull the competitiveness of retail outlets is a matter of great importance. The marketer always wants to identify the factors that will enhance their competitiveness to survive in the dynamic environment. The ultimate objective of the marketer is to make their consumer satisfy more than other competitors in the market so as to gain the loyalty of the consumer. This study will also help the marketer to identify those attributes which consumer takes into account while making a purchase decision form any retail outlet. The present research will enable the government to formulate suitable policies for unorganized retail sector, and will be useful for the retailers to get an insight into consumer purchase decision making behavior, which is the basis of growth of this business.

\section{Limitations of the Study and Suggestions for Future Research}

The study was limited to Agra region and its cities i.e. Mathura, Hathras and Aligarh, and as such, it has a 
limitation in terms of its impact on other regions due to geo-demographical diversity. This study is based on the behavior of the consumers, which is subject to change both from place to place and from time to time, and may even change in case of different product categories. Time constraints acted as another major limitation of this study.

Changing behavior of consumers might warrant many more studies in area. The competitiveness of unorganized retail outlets may be changed based on time and studies in future may have different and diversified results. Further comparative study can be done between organized and unorganized retail outlets to test the cost to investment pattern, market size, level of customer satisfaction etc. Due to time constraint survey was conducted at once, in future, longitudinal survey can be performed to test the level of competitiveness at different point of time.

\section{FINDINGS \& CONCLUSION}

This study has carried out in unorganized retail stores of selected cities with the objective of identifying the factors that influence the perception of shoppers towards unorganized retail outlets, to understand the shoppers perception towards the stores and to analyze the factors with various demographic characteristics of the shoppers. For achieving the objectives 21 attributes were identified from the past studies which have influence on perception towards unorganized retail outlets. The data were collected from 382 shoppers in four different cities of Agra region of Uttar Pradesh, India i.e. Mathura, Agra, Hathras and Aligarh. These locations have shown significant developments with respect to retailing. The results of different hypotheses taken in this study are:

\section{Table 12: Summary of Hypotheses Testing}

\begin{tabular}{|c|c|}
\hline Hypotheses & $\begin{array}{l}\text { Supported / Not } \\
\text { Supported }\end{array}$ \\
\hline $\begin{array}{l}\mathrm{H}_{\mathrm{a}} 1: \text { Factors influencing } \\
\text { competitiveness of unorganized } \\
\text { retail outlets are dependent to } \\
\text { each other. }\end{array}$ & Supported \\
\hline $\begin{array}{l}\mathrm{H}_{\mathrm{a}} 2 \mathrm{a} \text { : There is a significant } \\
\text { difference between factors } \\
\text { affecting shoppers preference } \\
\text { and different age category. }\end{array}$ & Supported \\
\hline $\begin{array}{l}\mathrm{H}_{\mathrm{a}} 2 \mathrm{~b} \text { : There is a significant } \\
\text { difference between factors } \\
\text { affecting shoppers preference } \\
\text { and different gender category. }\end{array}$ & Supported \\
\hline $\begin{array}{l}\mathrm{H}_{\mathrm{a}} 2 \mathrm{c} \text { : There is a significant } \\
\text { difference between factors } \\
\text { affecting shoppers preference } \\
\text { and different income category. }\end{array}$ & Supported \\
\hline $\begin{array}{l}\mathrm{H}_{\mathrm{a}} 2 \mathrm{~d} \text { : There is a significant } \\
\text { difference between factors } \\
\text { affecting shoppers preference } \\
\text { and different qualification } \\
\text { category. }\end{array}$ & Supported \\
\hline $\begin{array}{l}\mathrm{H}_{\mathrm{a}} 2 \mathrm{e} \text { : There is a significant } \\
\text { difference between factors } \\
\text { affecting shoppers preference } \\
\text { and different occupation } \\
\text { category. }\end{array}$ & Supported \\
\hline
\end{tabular}

However, in selected locations unorganized retailers have certain own strategies; but they have to modify their marketing and operational strategies to remain competitive in the market. The data collected from shoppers was analyzed using appropriate statistical tools to fulfill the objectives and come out with certain meaningful results. The results show that the 21 attributes taken were clubbed into 7 different factors namely convenience \& comfort, merchandise mix, smooth transaction \& exchange, store relationship, ambiance, value added facilities and attractive promotions. After identifying the factors their validity and reliability were tested which show that all the factors were valid as well as reliable based on the standardized estimates. Nearness to residence, all modes of payment accepted and quick handling of complaints are the most influential attributes in all four cities. There are certain attributes whose influence is affected by a particular city. There is a significant difference between various attributes based on the city like Products stocked with freshness, Availability of variety of brands and 
products, Discounts \& promotion schemes, Free home delivery, Quick handling of complaints, All modes of payment accepted, Nearness to residence and Order is taken over phone. Results show that there is a significant difference in Merchandise mix, smooth transaction \& exchange and ambiance based on different age categories. The difference in male and female preference for convenience \& comfort, ambiance and attractive promotions is statistically significant. The factor which differs significantly based on the income category is convenience \& comfort, smooth transaction \& exchange, store relationship and attractive promotions. Based on qualification store relationship, value added facilities and attractive promotions differ significantly. The factors which differ significantly based on occupation of the shoppers are smooth transaction \& exchange, ambiance and value added facilities. There are different factor which differs based on different demographics of the shoppers. Retail stores need to focus on these above factors to better influence the behavior of the shoppers based on to which segment they are targeting because perception of shoppers differs based on the demographics. After all the results from this study, it can be concluded that these preferred factors have the significant impact on the competitiveness of unorganized retail outlets to better survive in the dynamic environment.

\section{Reference}

[1] Amit, R., \& Schoemaker, P. J. (1993). Strategic assets and organizational rent. Strategic management journal, 14(1), 33-46.

[2] Arnold, S. J., Handelman, J., \& Tigert, D. J. (1998). The impact of a market spoiler on consumer preference structures. Journal of Retailing and Consumer Services, 5(1), 1-13.

[3] Barney, J. (1991). Firm resources and sustained competitive advantage. Journal of Management, 17(1), 99-120.

[4] Bharadwaj, S. G., Varadarajan, P. R., \& Fahy, J. (1993). Sustainable competitive advantage in service industries: a conceptual model and research propositions. The Journal of Marketing, 83-99.

[5]Byrne, B. M. (1994). Structural equation modeling with EQS and EQS/ Windows: Basic concepts, applications, and programming. Sage.

[6] Dholakia, N., Dholakia, R. R., \& Chattopadhyay, A. (2012). India's emerging retail systems: Coexistence of tradition and modernity. Journal of Macromarketing, 32(3), 252-265.

[7] Dyer, J. H., \& Singh, H. (1998). The relational view: Cooperative strategy and sources of interorganizational competitive advantage. Academy of management review, 23(4), 660-679.

[8] Fernie, J. (1995). The coming of the fourth wave: new forms of retail out-of-town development. International Journal of Retail \& Distribution Management, 23(1), 4-11.

[9] Fulmer, R. M., Gibbs, P., \& Keys, J. B. (1998). The second generation learning organizations: New tools for sustaining competitive advantage. Organizational Dynamics, 27(2), 7-20.

[10] Goel, B., \& Dewan, B. (2011). Factors affecting consumer preferences of shopping at organized retail stores in Punjab. Journal of Engineering, Sciences and Marketing Education, 4, 44-49.

[11] Goldman, A., Krider, R., \& Ramaswami, S. (1999). The persistent competitive advantage of traditional food retailers in Asia. Journal of Macromarketing, 19(2), 126-139.

[12] Goswami, P., \& Mishra, M. S. (2009). Would Indian consumers move from Kirana stores to organized retailers when shopping for groceries?. Asia Pacific Journal of Marketing and Logistics, 21(1), 127-143.

[13] Gupta, U., \& Tandon, V. K. (2013). Changing consumer preferences from unorganized retailing towards organized retailing. Journal of Emerging Knowledge on Emerging Markets, 4(1), 10.

[14] Hair, J. F., Anderson, R. E., Babin, B. J., \& Black, W. C. (2010). Multivariate data analysis: A global perspective (Vol. 7). Upper Saddle River, NJ: Pearson.

[15] Hawes, J. M., \& Crittenden, W. F. (1984). A taxonomy of competitive retailing strategies. Strategic Management Journal, 5(3), 275-287.

[16] Kalhan, A. (2007). Impact of malls on small shops and hawkers. Economic and Political Weekly, 2063-2066.

[17] Kline, R. B. (1998). Software review: Software programmes for structural equation modeling: Amos, EQS, and LISREL. Journal of Psychoeducational assessment, 16(4), 343-364.

[18] Lado, A. A., \& Wilson, M. C. (1994). Human resource systems and sustained competitive advantage: A competency-based perspective. Academy of management review, 19(4), 699-727.

[19] Mishra, S. (2008). New Retail Models in India: Strategic Perspective Analysis. Journal of Marketing \& Communication, 4(2).

[20] Oppewal, H., \& Timmermans, H. (1997). Retailer self-perceived store image and competitive position. The International Review of Retail, Distribution and Consumer Research, 7(1), 41-59.

[21] Porter, M. (1992). Competitive Strategy (1st ed.). New York: The Free Press.

[22] Ramakrishnan, K. (2010). The competitive response of small, independent retailers to organized retail: Study in an emerging economy. Journal of Retailing and Consumer Services, 17(4), 251-258. 
[23] Shaw, S. A., Dawson, J. A., \& Blair, L. M. A. (1992). Imported foods in a British supermarket chain: buyer decisions in Safeway. International Review of Retail, Distribution and Consumer Research, 2(1), 35-57.

[24] Sherman, E., Mathur, A., \& Smith, R. B. (1997). Store environment and consumer purchase behavior. Psychology and Marketing, 14(4), 361378.

[25] Sinha, P. K., \& Banerjee, A. (2004). Store choice behavior in an evolving market. International Journal of Retail \& Distribution Management, 32(10), 482-494.
[26] Swinyard, W. R. (1997). Retailing trends in the USA: competition, consumers, technology and the economy. International Journal of Retail \& Distribution Management, 25(8), 244-255.

[27] Ullman, J. B., \& Bentler, P. M. (2003). Structural equation modeling. John Wiley \& Sons, Inc.

[28] Zameer, A., \& Mukherjee, D. (2011). Food and grocery retail; patronage behavior of Indian urban consumers. South Asian Journal of Management, 18(1), 119. 